Cropley, M., Theadom, A., Pravettoni, G. \& Webb, G. (2008). The effectiveness of smoking cessation interventions prior to surgery: A Systematic Review. Nicotine \& Tobacco Research, 10, 407-12.

\title{
The effectiveness of smoking cessation interventions prior to surgery: A Systematic Review
}

\author{
Mark Cropley, Alice Theadom, Gabriella Pravettoni, Gemma Webb
}

Mark Cropley, PhD., and Gemma Webb, MSc., Department of Psychology, School of Human Sciences, University of Surrey, UK.; Alice Theadom, MSc. Department of Primary Care and Public Health, Brighton and Sussex Medical School, UK.; Gabriella Pravettoni, PhD., Department of Social Sciences, University of Milan, Italy.

Correspondence: Mark Cropley, PhD., Department of Psychology, School of Human Sciences, University of Surrey, Guildford, Surrey, GU2 7XH, UK. Tel.: +44 (0)1483 686928, Fax: +44 (0) 1483 689553; E-mail: mark.cropley@surrey.ac.uk

Key Words; smoking cessation, intervention, preoperative, surgery, smoking

Word Count: 2386 excluding references, including abstract and table 


\begin{abstract}
Stopping smoking prior to inpatient surgery is associated with a reduced risk of postoperative complications and subsequent morbidity. The objective of this review was to evaluate the effectiveness of smoking cessation interventions prior to surgery. The Cochrane Library Database, PsycINFO, EMBASE, Medline, and Cinahl databases were searched using the terms: ‘smok\$’, ‘smoking cessation’, 'tobacco’, ‘cigar\$’, ‘preop\$’, ‘operati\$’, ‘surg\$’, 'randomi*ed control\$ trial’, ‘intervention’, 'program\$', ‘cessation’, 'abstinen\$', ‘quit’. Further articles were obtained from reference lists. The search was limited to articles on adults, written in English and published up to December 2006. Only randomised control trials (RCTs) that incorporated smoking cessation interventions to help patients awaiting elective surgery were included. Nine studies met the inclusion criteria. Methodological quality was assessed by all reviewers to verify that only genuine RCTs were reviewed. The findings revealed that quit rates ranged from $18 \%-93 \%$ in patients receiving a smoking intervention (mean 55\%), compared to a range of $2 \%$ - $65 \%$ of controls $($ mean $=26.5 \%)$. Two studies examined smoking status at six months but these revealed no significant difference in abstinent rates between patients who had received an intervention and those that had not. It is concluded that smoking cessation interventions prior to surgery, are effective in helping patients to 'quit' smoking. However such effects appear to be short-lived. Future research needs to examine intervention and patient factors to see whether tailoring the smoking cessation intervention specifically to the patient improves overall abstinent rates.
\end{abstract}

\title{
240 Words
}




\section{Introduction}

Regular smokers have an increased risk of postoperative complications compared to individuals who have never smoked, or have recently quit smoking (Moller, \& Villebro, 2006; Theadom \& Cropley, 2006). Complications vary, and are dependent upon the diagnosis, but can include heightened blood pressure (Ratner et al., 2004) wound infection (Sorensen, \& Jorgensen, 2003) and increased mortality (Ashraf, Mortasawi, Grayson, \& Oo, 2004). Thus smoking cessation prior to surgery has a direct effect on health postoperatively and has been deemed advisable by many health professionals (Fiore, Bailey, Cohen, \& Dorfman, 2000; Moller, Villebro, Pedersen, \& Tonnesen, 2002; Theadom \& Cropley, 2006).

Smokers constitute approximately 30\% of patients undergoing surgery and the experience of hospitalization is believed to make patients more amenable to health behaviour change interventions, smoking cessation in particular (Wewers, Bowen, Stanislaw, \& Desimone, 1994). Patients awaiting surgery may be more motivated to change their smoking habits, especially if they believe that their need for surgery was partly caused by smoking. In addition, patients will be mindful that their recovery could be adversely affected if they continue to smoke pre or postsurgery. Therefore the issues and motivations for stopping smoking may be different for patients who smoke within this context since they have a specific event to work towards.

Many health care environments, including hospitals, have implemented no smoking policies. Thus inpatients are ideally placed to receive smoking cessation advice and counselling. Wolfenden et al (2005) identified three characteristics that make preoperative clinics appealing for delivering smoking cessation interventions: 1) smoking behaviour forms part of the normal preoperative assessment, 2) during these assessments patients come into contact with many different health professionals and each one has the 
opportunity to provide smoking cessation advice, 3) contacts with health professionals continue long after surgery, thereby additional support can be delivered routinely. Smoking cessation interventions vary widely in their nature and although systematic reviews on the effect of preoperative smoking cessation on postoperative complications are available (Moller, \& Villebro, 2006; Theadom \& Cropley, 2006) the effectiveness of interventions to support smoking cessation before surgery needs to be established to inform preoperative clinical practice.

\section{Objectives}

The main objective of this review is to evaluate the effectiveness of preoperative smoking cessation interventions prior to surgery within a hospital setting.

\section{Criteria for inclusion}

\section{Study Design}

Randomised Controlled Trials

\section{Participants}

Smokers awaiting elective surgery classified as smokers either by self-report, carbon monoxide (CO) readings or cotinine. The studies included patients who were over 18 years old. Studies in which smoking cessation programmes were only offered postsurgery were not included.

\section{Search strategy for identification of studies}

Electronic databases were searched using the Knowledge Access 24 hours a day internet based resource (KA24). Medline (1950-date), EMBASE (1974-date), PsycINFO (1806-date) and Cinahl (1982-date) 
databases were searched using the search terms: 1, 'smok\$’; 2, 'smoking cessation’; 3, 'tobacco’; 4, ‘cigar\$’; 5, ‘preop\$’; 6, ‘operati\$’; 7, ‘surg\$’; 8, ‘randomi*ed control\$ trial’; 9, ‘intervention’; 10, ‘program\$'; 11, 'cessation’; 12, 'abstinen\$’; 13, ‘quit’. The search was refined by combining participant, context and research design search terms to ensure the elicited articles were relevant to the research question as suggested by Glasziou and colleagues (Glasziou, Irwig, Bain, \& Colditz, 2001) Step one, '1 OR 2 OR 3 OR 4 OR 9 OR 10 OR 11 OR 12 OR 13’; Step two ‘5 OR 6 OR 7’; Step three, ‘14 AND 15 AND 8'. The Cochrane Library database and reference lists were also searched to identify any further articles relevant to the aims of the review.

\section{Methods and Results}

The initial search elicited 1130 abstracts, each of which was read by the reviewers for possible inclusion. Lack of agreement was resolved by discussion and consensus. Based on the inclusion criteria, 51 full text articles were obtained but following further scrutiny by the reviewers 42 of these were excluded. Nine full text articles were retained in this review (Andrews, Bale, Chu, Crame, \& Aveyard, 2006; McHugh et al., 2001; Moller, et al., 2002; Myles et al., 1996; Myles, Leslie, Angliss, Mezzavia, \& Lee, 2004; Molyneux et al., 2003; Ratner et al., 2004; Sorensen, \& Jorgensen, 2003; Wolfenden et al., 2005). Studies were excluded if the smoking cessation intervention was delivered postsurgery, or they were not genuine RCTs.

\section{Description of studies}

Table 1 summarises the studies included in this review. Of the nine studies, three were conducted the UK, (Andrews et al., 2006; McHugh et al., 2001; Molyneux et al., 2003) three in Australia, (Myles et al., 1996; Myles et al., 2004; Wolfenden et al., 2005) two in Denmark (Moller, et al., 2002; Sorensen, \& Jorgensen, 
2003) and one in the USA (Ratner et al., 2004). In total 1507 patients participated and the number of participants in the RCTs ranged from 47 to 363. 
Table 1. Characteristics of the studies included in the review

\begin{tabular}{|c|c|c|c|c|c|c|c|c|c|c|c|}
\hline Authors & Country & $\begin{array}{l}\text { No. of } \\
\text { patients }\end{array}$ & Type of surgery & $\begin{array}{l}\text { Types of } \\
\text { intervention }\end{array}$ & $\begin{array}{l}\text { Pre-operative } \\
\text { period }\end{array}$ & $\begin{array}{l}\text { Follow-up } \\
\text { period }\end{array}$ & $\begin{array}{l}\% \text { Abstinent } \\
\text { before } \\
\text { surgery }\end{array}$ & $\begin{array}{l}\% \text { Abstinent } \\
6 \text { months } \\
\text { post surgery }\end{array}$ & $\begin{array}{l}\text { Smoking } \\
\text { status } \\
\text { verification } \\
\text { methods }\end{array}$ & $\begin{array}{l}\text { Tobacco } \\
\text { types } \\
\text { included }\end{array}$ & Brief summary of results \\
\hline $\begin{array}{l}\text { Andrews et } \\
\text { al., (2006) }\end{array}$ & UK & 101 & Elective & $\begin{array}{l}\text { Consultant } \\
\text { 'stopping smoking' } \\
\text { letter }\end{array}$ & 1-2 weeks & $\begin{array}{l}\text { None } \\
\text { (day of } \\
\text { surgery) }\end{array}$ & $\begin{array}{l}18 \% \text { Exp; } \\
8 \% \text { Con, } \\
\text { (sig.) }\end{array}$ & Not studied & Self-report & $\begin{array}{l}\text { Not } \\
\text { specified }\end{array}$ & $\begin{array}{l}\text { Patients receiving the } \\
\text { 'stopping smoking' letter } \\
\text { had a higher relative risk } \\
\text { of smoking cessation } \\
\text { compared to those who } \\
\text { did not }\end{array}$ \\
\hline $\begin{array}{l}\text { McHugh et } \\
\text { al., (2001) }\end{array}$ & UK & 98 & CABG & $\begin{array}{l}\text { Health education } \\
\text { sessions based on } \\
\text { readiness to change } \\
\text { and discussion of } \\
\text { behavioural risk } \\
\text { factors }\end{array}$ & $\begin{array}{l}\text { Approx. } 8.5 \\
\text { months }\end{array}$ & $\begin{array}{l}\text { Not } \\
\text { specified }\end{array}$ & $\begin{array}{l}25 \% \text { Exp; } \\
2 \% \text { Con, } \\
\text { (sig.) }\end{array}$ & Not studied & Self-report & Cigarettes & $\begin{array}{l}\text { Patients receiving the } \\
\text { nurse-led intervention } \\
\text { were significantly more } \\
\text { likely to stop smoking than } \\
\text { patients receiving usual } \\
\text { care }\end{array}$ \\
\hline $\begin{array}{l}\text { Moller et } \\
\text { al., (2002) }\end{array}$ & Denmark & 120 & $\begin{array}{l}\text { Hip or knee } \\
\text { replacement } \\
\text { therapy }\end{array}$ & $\begin{array}{l}\text { Counselling plus } \\
\text { NRT }\end{array}$ & 6-8 weeks & $\begin{array}{l}10 \text { days } \\
\text { post- } \\
\text { surgery }\end{array}$ & $\begin{array}{l}60 \% \text { Exp } \\
7 \% \text { Con } \\
\text { (10 days } \\
\text { postsurgery), } \\
\text { (sig.) }\end{array}$ & Not studied & CO reading & $\begin{array}{l}\text { Not } \\
\text { specified }\end{array}$ & $\begin{array}{l}\text { Patients receiving the } \\
\text { intervention 6-8 weeks } \\
\text { prior to surgery were } \\
\text { significantly more likely to } \\
\text { stop smoking than controls }\end{array}$ \\
\hline $\begin{array}{l}\text { Myles et } \\
\text { al., (1996) }\end{array}$ & Australia & 363 & $\begin{array}{l}\text { Elective or semi- } \\
\text { elective surgery }\end{array}$ & $\begin{array}{l}3 \text { minute intra- } \\
\text { operative tape }\end{array}$ & $\begin{array}{l}\text { Delivered } \\
\text { during surgery }\end{array}$ & $\begin{array}{l}2 \& 6 \\
\text { months } \\
\text { post- } \\
\text { surgery }\end{array}$ & $\begin{array}{l}9.5 \% \text { Exp, } \\
7.9 \% \text { Con, } \\
\text { (n.s) }\end{array}$ & Not studied & $\begin{array}{l}\text { Self-report } \\
\text { cO reading }\end{array}$ & $\begin{array}{l}\text { Cigarettes } \\
>2 \text { per } \\
\text { day }\end{array}$ & $\begin{array}{l}\text { Intra-operative tapes did } \\
\text { not significantly affect } \\
\text { smoking cessation }\end{array}$ \\
\hline $\begin{array}{l}\text { Myles et } \\
\text { al., (2004) }\end{array}$ & Australia & 47 & Elective surgery & Bupropion & On waiting list & $\begin{array}{l}3 \text { weeks \& } \\
6 \text { months } \\
\text { post- } \\
\text { surgery }\end{array}$ & $\begin{array}{l}38 \% \text { Exp } \\
9 \% \text { Con, } \\
\text { (sig.) }\end{array}$ & $\begin{array}{l}13 \% \text { Exp } \\
5 \% \text { Con } \\
\text { (n.s.) }\end{array}$ & $\begin{array}{l}\text { Self-report } \\
\text { co reading }\end{array}$ & $\begin{array}{l}\text { Cigarettes } \\
>10 \text { per } \\
\text { day }\end{array}$ & $\begin{array}{l}\text { Smokers awaiting elective } \\
\text { surgery are more likely to } \\
\text { have stopped smoking } \\
\text { when treated with } \\
\text { bupropion compared to } \\
\text { controls }\end{array}$ \\
\hline
\end{tabular}


Table 1. Continued...

\begin{tabular}{|c|c|c|c|c|c|c|c|c|c|c|c|}
\hline $\begin{array}{l}\text { Ratner et } \\
\text { al., ( 2004) }\end{array}$ & USA & 237 & Elective surgery & Counselling \& NRT & 1-3 weeks & $\begin{array}{l}24 \text { hrs } \\
\text { prior to } \\
\text { surgery, } 6 \\
\& 12 \\
\text { months } \\
\text { post } \\
\text { surgery }\end{array}$ & $\begin{array}{l}73 \% \text { Exp } \\
53 \% \text { Con, } \\
\text { (sig.) }\end{array}$ & $\begin{array}{l}31.2 \% \text { Exp } \\
20.2 \% \text { Con } \\
\text { (n.s.) }\end{array}$ & $\begin{array}{l}\text { Self-report, } \\
\text { CO reading \& } \\
\text { urinary } \\
\text { cotinine }\end{array}$ & Cigarettes & $\begin{array}{l}\text { Patients in the intervention } \\
\text { group were significantly } \\
\text { more likely to be abstinent } \\
24 \text { hrs prior to surgery } \\
\text { compared to controls }\end{array}$ \\
\hline $\begin{array}{l}\text { Sorensen } \\
\& \\
\text { Jorgensen } \\
(2002)\end{array}$ & Denmark & 57 & $\begin{array}{l}\text { Open colonic or } \\
\text { rectal }\end{array}$ & Counselling \& NRT & 2-3 weeks & $\begin{array}{l}30 \text { days } \\
\text { post- } \\
\text { surgery }\end{array}$ & $\begin{array}{l}\text { *93\% Exp, } \\
50 \% \text { Con, } \\
\text { (sig.) }\end{array}$ & Not studied & $\begin{array}{l}\text { Self-report, } \\
\text { cO reading \& } \\
\text { cotinine }\end{array}$ & Unclear & $\begin{array}{l}\text { Patients receiving the } \\
\text { intervention 2-3 weeks } \\
\text { before surgery either quit } \\
\text { smoking or smoked } \\
\text { significantly less tobacco } \\
\text { post-surgery compared to } \\
\text { controls }\end{array}$ \\
\hline $\begin{array}{l}\text { Wolfenden } \\
\text { et al., } \\
\text { (2005) }\end{array}$ & Australia & 210 & $\begin{array}{l}\text { Non-cardiac } \\
\text { elective surgery }\end{array}$ & $\begin{array}{l}\text { Counselling, } \\
\text { tailored self-help } \\
\text { material \& NRT }\end{array}$ & 1-2 weeks & $\begin{array}{l}24 \text { hrs } \\
\text { prior to } \\
\text { surgery \& } \\
3 \text { months } \\
\text { post- } \\
\text { surgery }\end{array}$ & $\begin{array}{l}78 \% \text { Exp, } \\
65 \% \text { Con, } \\
\text { (sig.) }\end{array}$ & Not studied & Self-report & Cigarettes & $\begin{array}{l}\text { Provision of preoperative } \\
\text { smoking cessation } \\
\text { intervention increased } \\
\text { abstinence }>24 \text { hours } \\
\text { before surgery }\end{array}$ \\
\hline
\end{tabular}

Key: $\mathrm{CABG}=$ Coronary Artery Bypass Graft surgery; Exp = Experimental Group; Con = Control Group; $n$.s. = non significant; sig. = statistically significant $*=$ post-operatively abstinence or reduction by more than half or normal daily rate 
A number of different intervention methods were used in the papers: six studies used some form of counselling (McHugh et al., 2001; Moller, et al., 2002; Molyneux et al., 2003; Ratner et al., 2004; Sorensen, \& Jorgensen, 2003; Wolfenden et al., 2005), five studies used counselling together with Nicotine Replacement Therapy (NRT) (Moller, et al., 2002; Molyneux et al., 2003; Ratner et al., 2004; Sorensen, \& Jorgensen, 2003; Wolfenden et al., 2005), one study used only NRT (bupropion) (Myles et al., 2004), one study used a letter offering smoking cessation advice (Andrews et al., 2006), one study delivered smoking cessation advice via an audio cassette (Myles et al., 1996) and one study used counselling, NRT and offered self-help material tailored to individual needs (Wolfenden et al., 2005). Thus most interventions used a multifaceted behavioural approach.

Three studies used self-report as the sole method of eliciting smoking status (Andrews et al., 2006; McHugh et al., 2001; Wolfenden et al., 2005) four used self-report together with CO readings (Myles et al., 1996; Myles et al., 2004; Ratner et al., 2004; Sorensen, \& Jorgensen, 2003), with two of these also using cotinine to verify smoking status, (Ratner et al., 2004; Sorensen, \& Jorgensen, 2003), and two studies used CO readings only (Moller, et al., 2002; Molyneux et al., 2003). The preoperative period varied between studies and in one study this was not reported (Myles et al., 2004), but in the remainder time ranged from during surgery (Myles et al., 1996) to 8.5 months.(McHugh et al., 2001) The follow-up period ranged from 1 day before surgery (Wolfenden et al., 2005), to 12 months after surgery (Ratner et al., 2004; Molyneux et al., 2003). The majority of studies reported cigarette use as the tobacco type identified (McHugh et al., 2001; Molyneux et al., 2003; Myles et al., 1996; Myles et al., 2004; Ratner et al., 2004; Wolfenden et al., 2005), but in three studies this was unclear or not specified (Andrews et al., 2006; Moller, et al., 2002; Sorensen, \& Jorgensen, 2003). 
The overwhelming majority, approximately 89\%, of the studies reviewed revealed that the smoking cessation intervention offered was effective (Andrews et al., 2006; McHugh et al., 2001; Moller, et al., 2002; Molyneux et al., 2003; Myles et al., 2004; Ratner et al., 2004; Sorensen, \& Jorgensen, 2003; Wolfenden et al., 2005). Success rates varied between studies, from 18\% (Andrews et al., 2006) to 93\% Sorensen, \& Jorgensen, 2003; with a mean success rate of 55\%. Success rates for individuals allocated to the control condition (those receiving usual care) ranged from 2\% (McHugh et al., 2001) to 65\% (Wolfenden et al., 2005) with a mean of 26.5\%. The follow-up periods varied from immediately after surgery to 12 months post-surgery. However, of the two studies that examined follow-up rates at 6 months (Myles et al., 2004; Ratner et al., 2004), neither revealed a significant difference in smoking cessation between intervention and control participants.

\section{Methodological Quality}

The quality criterion for assessment of experimental studies by the Centre for Research and Dissemination (2001) was used to assess the methodological quality of the studies identified. This explored the randomisation procedure, the eligibility criteria and blinding of researchers to the treatment condition, in addition to the description of the intervention delivered. Eight of the nine studies included in the review had clearly outlined eligibility criteria and all reported comparison data for the two experimental groups. The randomisation procedures were clearly specified in eight of the nine articles (Andrews et al., 2006; Moller, et al., 2002; Molyneux et al., 2003; Myles et al., 1996; Myles et al., 2004; Ratner et al., 2004; Sorensen, \& Jorgensen, 2003; Wolfenden et al., 2005). Two studies used computer generated random number tables (Ratner et al., 2004; Wolfenden et al., 2005), three used sealed opaque envelopes or opaque bags (Andrews et al., 2006; Moller, et al., 2002; Sorensen, \& Jorgensen, 2003) and three studies used 
random number lists (Molyneux et al., 2003;Myles et al., 1996; Myles et al., 2004). One study reported that patient allocation was random but did not provide details of the procedure (McHugh et al., 2001).

\section{Discussion}

There is clearly a shortage of RCTs that have investigated the effects of smoking cessation interventions prior to hospitalised surgery. However, from the results of this review, the general conclusion drawn is that preoperative smoking cessation interventions delivered in a hospital setting are effective in helping patients to 'quit' smoking prior to surgery. The success rate of 55\% for the preoperative interventions is slightly higher than smoking cessation rates at 4 week follow up (45\%) observed in the wider community (Department of Health, 2001). It needs to be acknowledged that many smokers will be aware of, or have been advised of the risks smoking has on surgical complications, which may explain the higher than expected quit rates for the controls (26.5\%). Furthermore postoperative discomfort may also influence smoking habits irrespective of any smoking cessation intervention.

It was not possible to make salient comparisons between studies as each differed with respect to type of surgery, type of intervention, and follow-up period. In addition, it is not known how effective such interventions are long-term, as only two of the nine studies examined cessation rates at 6 months (Myles et al., 1996; Myles et al., 2004). Both studies reported no difference in abstinent rates at 6 months between those who received the intervention prior to surgery and those that did not. Such findings, if supported by further research, would suggest that follow-up smoking cessation support should be made available for longer as this may improve cessation rates long-term (Wewers et al., 1994). The effectiveness of the smoking cessation interventions did not appear to be related to the type of surgery since smoking cessation interventions were found to be effective across surgical procedures. Future research needs to identify if 
there are any intervention or patient factors that are associated with greater success as there were too few studies to definitively answer this question within this review. Nonetheless, the overall conclusion that can be taken from this review is that smoking cessation interventions are effective within hospital settings for reducing smoking rates prior to surgery.

\section{REFERENCES}

Andrews, K., Bale, P., Chu, J., Cramer, A., \& Aveyard, P. (2006). A randomized controlled trial to assess the effectiveness of a letter from a consultant surgeon in causing smokers to stop smoking pre-operatively. Public Health, 120, 356-358.

Ashraf, M.N., Mortasawi, A., Grayson, A.D., \& Oo, A.Y. (2004). Effect of smoking status on mortality and morbidity following coronary artery bypass surgery. Thoracic and Cardiovascular Surgeon, 52, 268273.

Centre for Research and Dissemination. (2001). CRD Report 4, 2nd Edition. York, UK.

Department of Health. Statistics on smoking cessation services in health authorities: England, April to December 2000. (2001). London, Department of Health press release.

Fiore, M.C., Bailey, W.C., Cohen, S.J. \& Dorfman, S.F. (2000) A clinical practice guideline for treating tobacco use and dependence: A US Public Health Service report. Journal of the American Medical Association, 283, 3244-3254. 
Glasziou, P., Irwig, L., Bain, C., \& Colditz, G. (2001). Systematic Reviews in Health Care: A Practical Guide. Cambridge University Press.

McHugh, F.M., Lindsay, G.M., Hanlon, P., Hutton, I., Brown, M.R., Morrison, C., \& Wheatley, D.J. (2001). Nurse led shared care for patients on the waiting list for coronary artery bypass surgery: a randomised control trial. Heart, 86, 317-323.

Moller, A., \& Villebro, N. (2006). Interventions for preoperative smoking cessation (Review). The Cochrane Collaboration, 2, 1-13.

Moller, A.M., Villebro, N., Pedersen, T., \& Tonnesen, H. (2002). Effect of preoperative smoking intervention on postoperative complications: a randomised clinical trial. Lancet, 359, 114-117.

Molyneux, A., Lewis, S., Leivers, U., Anderton, A., Antoniak, M., Brackenridge, A., Nilsson, F., McNeill, A., West, R., Moxham, J., \& Britton, J. (2003). Clinical trial comparing nicotine replacement therapy (NRT) plus brief counselling, brief counselling alone, and minimal intervention on smoking cessation in hospital inpatients. Thorax, 58, 484-488.

Myles, P.S., Hendrata, M., Layher, Y., Williams, N.J., Hall, J.L., Moloney, J.T., \& Powell J. (1996). Double-blind, randomised trial of cessation of smoking after audiotape suggestion during anaesthesia. British Journal of Anaesthesia, 76, 694-698. 
Myles, P.S., Leslie, K., Angliss, M., Mezzavia, P., \& Lee, L. (2004) Effectiveness of Buropion as an aid to stopping smoking before elective surgery: a randomised controlled trial. Anaesthesia, 59, 1053-1058.

Ratner, P. A., Johnson, J.L., Richardson, C.G., Bottorff, J.L., Moffat, B., Mackay, M., Fofonoff, D., Kingsbury, K., Miller, C., \& Budz, B. (2004). Efficacy of a smoking-cessation intervention for electivesurgical patients. Research in Nursing \& Health, 27, 148-161.

Sorensen, L.T., \& Jorgensen, T. (2003). Short-term pre-operative smoking cessation intervention does not affect postoperative complications in colorectal surgery: A randomized clinical trial. Colorectal Disease, 5, 347-352.

Theadom, A., \& Cropley, M. (2006). Effects of preoperative smoking cessation on the incidence and risk of intraoperative and postoperative complications in adult smokers: a systematic review. Tobacco Control, 15, 352-358.

Wewers, M.E., Bowen, J.M., Stanislaw, A.E., Desimone, V.B. (1994). A nurse-delivered smoking cessation intervention among hospitalized postoperative patients - influence of a smoking-related diagnosis: A pilot study. Heart \& Lung, 23, 151-156.

Wolfenden, L., Wiggers, J., Knight, J., Campbell, E., Rissel, C., Kerridge, R., Spigelman, A.D., \& Moore K. (2005). A programme for reducing smoking in pre-operative surgical patients: randomised controlled trial. Anaesthesia, 60, 172-179. 